\title{
The Use of Interactional Metadiscourse Markers in English Book Reviews Across Disciplines
}

\author{
Neda Zal \\ Department of Foreign Languages, University of Kashan, Iran \\ Mohammad Raouf Moini \\ Department of Foreign Languages, University of Kashan, Iran
}

\begin{abstract}
The study aimed to investigate the frequency and type of stance and engagement features in each move of book reviews of soft and hard disciplines according to Hyland's (2005) Interactional Metadiscourse taxonomy. A corpus of 102 book reviews published by 30 first quality journals in 6 disciplines was randomly selected and analyzed. The results indicated a significant difference between book reviews in terms of stance markers. Furthermore, Move 2 (Outlining) enjoyed the highest frequency of stance features, while move 4 (Evaluation) contained the least frequency of stance features. Also, a significant difference was observed in the use of stance markers in Introducing, Outlining, and Highlighting. However, using engagement markers, the significant difference was only in the highlighting.
\end{abstract}

Index Terms — engagement, hard discipline, metadiscourse, interactional metadiscourse, soft discipline, stance

\section{INTRODUCTION}

Categorization of communicative acts according to their form and function is referred to as genre analysis in linguistics. Various definitions have been presented in the area of applied linguistics for genre. According to Miller (1994), genre is a rhetorical action that is based on rhetorical practice. Swales (1990) states that genre is "a class of communicative events, the members of which share some set of communicative purposes" (p. 58). Hyland (2008) claims that genre is "a term for grouping texts together, representing how writers typically use language to respond to recurring situations"; he further claimed that genre originates from the idea that "members of a community usually have little difficulty in recognizing similarities in the texts they use frequently" (p. 543). Furthermore, the addressees of an academic text aim to "predict lines of thought, interrogate authors on their positions and evaluate work for its usefulness and importance to their own research" (Hyland, 1994, p. 239). Book review which is considered as a sub-category of academic discourse genre (Hyland, 2004; Hyland \& Diani, 2009) aims to give information about new books in a specific field. Besides, this genre aims "to evaluate the scholarly work of a professional peer within the scholar community" (Vande Kopple, p. 40). Jalilifar, Hayati, and Don (2018) believe that among various academic genres, book reviews are functionally different. They include genres with the same content but different goals. As Hyland (2000) stated, the book review is "a site where the interpersonal stakes are much higher" (p. 41). Hyland (2002) stated that:

Book reviews are more interactively complex than research papers as they don't simply respond to a general body of more-or-less impersonal literature. Instead there is a direct, public, and often critical encounter with a particular text and therefore with its author, who must be considered as a primary audience of the review. While writers of research articles commonly avoid critical references, reviews are centrally evaluative (p. 41).

Ghazanfari, Barani, and Rokhsari (2018) believe that in academic discourse metadiscourse has attracted much attention as a central rhetorical tool that could affect the ability of the members of the academic community to communicate. Metadiscourse, as a rather new approach, has been used in discourse analysis as well as studies in language education to present a framework for a more comprehensive understanding of interactions between writers, readers, and texts (Hyland, 2005a, as cited in Jalilifar, Hayati, \& Don, 2018).

The importance of book reviews seems to be overlooked. In addition, mastering writing skill is one of the challenges writers encounter with. When it comes to writing book reviews in English the issue even gets more exacerbated. This is due to the fact that writers are not well informed of the genre of the book reviews and need to be quite aware of this genre and devices helping them to communicate effectively with their readers. In other words, as "the book review process is considered as a face-threatening act, being aware of items such as hedging and boosters can help ameliorate this problem and "attenuate unwelcome effects on the reviewer and makes the criticism more palatable" (Gea Valor, 2000, p.146). Junqueira and Cortes (2014) believe that cross-cultural studies on book reviews are particularly important to inexperienced researchers intend to contribute to the international academic fields. Based on the above, and according to the existing literature, a gap is felt within the area of writing the book reviews, especially of soft and hard disciplines. Yang (2014) believes that "knowledge in the hard science domain tends to be relatively analytical, structured and cumulative to establish empirical uniformities, while the soft science domain emphasizes interpretation, 
diversity, and mutual understanding, and also allows for more tolerance on the part of readers" (p.64). In the present study, it was tried to investigate whether there was any significant difference between English book reviews of soft and hard disciplines in the use of stance discourse markers and whether there is any significant difference between English book reviews of soft and hard disciplines in the use of engagement discourse markers.

The present study aimed to answer the following research questions:

1. Is there any significant difference between English book reviews of soft and hard disciplines in the use of different stance discourse markers?

2. Is there any difference between English book reviews of soft and hard disciplines in the use of different engagement discourse markers?

3. Is there any difference between English book reviews of soft and hard disciplines in the use of stance markers in different moves of book reviews?

4. Is there any difference between English book reviews of soft and hard disciplines in the use of engagement markers in different moves of book reviews?

\section{LITERATURE REVIEW}

As one of the main elements of book reviews, metadiscourse has gained much attention during the past few decades (Hyland, 2005a). Metadiscourse is "the self-reflective expressions used to negotiate interactional meanings in a text, assisting the writer (or speaker) to express a viewpoint and engage with readers as members of a particular community" (Hyland, 2005a, p.37)._Metadiscourse markers are categorized into two groups, namely, interactive and interactional metadiscourse markers. Interactive metadiscourse markers provide the organization of texts and enhance readers' comprehension, while interactional metadiscourse shows the writer's attitude toward readers to construct the text (Hyland, 2005a).

Hyland (2005) has provided a model to justify the interaction between writers and readers. He states that writing aims not only to produce some texts or explain an external reality but also to construct social relations with the readers. Within this model, the interaction in academic writing occurs within two elements, namely, stance and engagement. Stance markers include attitude markers, boosters, hedges, and self-mentions and engagement includes personal asides, reader pronouns, appeal to shared knowledge, and appeals to directives and questions.

\section{A. Stance Features}

Hedges: "mark the writer's reluctance to present propositional information categorically" (Hyland 2010, p.129). Hedges are utterances used by the writers to present alternative viewpoints and show commitment to the proposition. Within hedges, information is given as an opinion rather than fact and the writer gives weight to it through words like perhaps, possible, or might.

a. Shield: Shields include all modal verbs which express possibility; adverbs of probability like 'probably, in addition to their derivations; and, verbs which relate to the probability of a proposition or a hypothesis being true like 'to suggest, known as epistemic verbs.

b. Approximate: Approximators like about, somehow, some, kind of, sort of are the words which change or give an alternative meaning to a proposition.

c. Expressions: like 'to our knowledge' and 'I believe' which express the authors' doubt are among the expressions.

Boosters are a class of metadiscourse markers which let writers express their level of certainty in what they say. Boosters are words like clearly, definitely, certainly, should, and of course.

Attitude Markers show the "writer's agreement, frustration, and so on, rather than commitment" (Hyland, 2008, p. 8). Attitude is shown by attitude verbs (e.g. prefer), sentence adverbs (unfortunately), and adjectives (remarkable).

Self-Mention: Self-mention like I, we, my, me, and our which show affective and interpersonal information (Hyland, 2001).

\section{B. Engagement Markers}

Reader pronouns are those markers which lead readers into a discourse like reader pronouns such as you and your. (Hyland, 2010).

Directives: are defined "as utterances which instruct the reader to perform an action or to see things in a way determined by the writer" (Hyland, 2002a, p.216). Imperatives like consider and note are examples of directives.

Personal aside: Hyland (2005b) believes that personal asides as a main reader-oriented strategy "allow writers to address readers directly by briefly interrupting the argument to offer a comment on what has been said" (p.183).

Appeals to shared knowledge: is "the presence of explicit markers where readers are asked to recognize something as familiar or accepted" (Hyland, 2005b, p. 184).

Questions: allow writers "to invoke explicitly the involvement of their readers in the discourse, addressing the perceptions, interests, and needs of a potential audience" (Hyland, 2002b, p. 529).

Despite the importance of book reviews in academia (Hyland, 2000), only in the past decade studies started to be published about their rhetorical patterns and their linguistic features, for example, praise and criticism (Hyland, 2000). 
Accordingly, the present paper aimed to investigate the metadiscourse markers in the book reviews published in the field of soft and hard sciences.

\section{Empirical Background}

A large number of studies have focused on the type and function of metadiscourse resources in different genres, including textbooks (Hyland, 2002), advertisements (Fuertes-Olivera et al., 2001), research papers (Hyland, 2002a, 2005; McGrath \& Kuteeva, 2012; Abdollahzadeh, 2011); and book reviews (Tse \& Hyland, 2006). Furthermore, to find out some cross-cultural differences, several studies (e.g. Yang, 2013) have investigated the use of metadiscourse markers by speakers of different languages.

Ebrahimi (2018) investigated metadiscourse markers in texts from university books Published in Iran and compared them with books printed in Oxford University Press. It was shown that the texts published by Oxford University Press used more interactive and more interactional resources.

Jalilifar, Hayati, and Don (2018) compared book reviews and blurbs in four disciplines of applied linguistics, literature, history, and psychology. The corpus included 200 books and 4,282 blurbs were investigated. Hyland's (2005a) classification of metadiscourse markers was employed. The results revealed that the frequency and type of metadiscourse markers in blurbs and book reviews are genre -dependent. Metadiscourse markers were greater in the book reviews than in the blurbs.

Salahshoor and Afsari (2017) investigated interactional metadiscourse in natural and social science master theses. Thirty natural and social science master theses in six disciplines were chosen. This study analyzed only the discussion and conclusion sections of five master theses. Hyland's (2005) classification was used. The results showed that the total number of interactional metadiscourse markers in social science master theses was more than natural science master theses. Hedges were the most frequent marker in both corpora while attitude markers in social science and self-mention in natural science were the least favored role.

Gezegin (2016) investigated how interpersonal metadiscourse was used in Turkish and English book reviews. About 150 published book reviews published in English and Turkish were analyzed. Hyland's (2000) metadiscourse model was used. The findings showed that the total number of interpersonal metadiscourse features was higher in the English book reviews compared with those published in Turkish. There were differences in the use of hedges between the two languages.

Junqueira and Cortes (2014) in a study compared interpersonal metadiscourse in book reviews in Brazilian Portuguese and English. Hyland's (2000) metadiscourse framework was employed. The corpus consisted of 180 academic book reviews across two languages, Brazilian Portuguese (BP) and English, in three fields of study, namely, History, Applied Linguistics, and Psychology. All book reviews were published in international academic journals between 2001-2010. The total number of interpersonal metadiscourse features (normalized per 1000 words) was higher in the English corpus than in the BP corpus.

Ghafoori and Oghbatalab (2012) compared the use of metadiscoursal markers between the male and female native English writers. Like previous studies, Hyland's (2005) model was employed to identify the metadiscoursal features. The results revealed no significant difference between English male and female writers' use of metadiscourse. On the other hand, there were significant differences in the distribution of metadiscoursal elements.

Using Hyland's (2005) framework, McGrath \& Kuteeva (2012) investigated stance and engagement markers in 25 research articles in the field of mathematics. The results showed a lower frequency of hedges and attitude markers compared to Hyland's (2005a). It was also shown that pure mathematics research articles can apply Hyland's framework.

Atai and Sadr (2008) also studied the use of hedges and boosters in 649 academic article abstracts from eight journals of applied linguistics. Hedges in abstracts published in journals published in English were more frequent than journals published in Chinese and boosters were found to be more in the abstracts of empirical research articles compared with non-empirical academic articles.

Similarly, Faghih and Rahimpor (2009) compared metadiscourse markers in discussion sections of applied linguistics research articles in English and Persian. Both groups used interactive metadiscourse markers more than interactional metadiscourse markers. Hyland (2005) compared interactive and interactional metadiscourse in 240 articles from 8 fields study. The result indicated that interactive and interactional metadiscourse markers were more frequent in the soft discipline than the hard discipline.

One of the most complete analyses of book reviews is what was done by Hyland (2004). Hyland investigated praise and criticism in 160 book reviews of different disciplines including humanities, social sciences, and science. The data was collected from 28 academic journals. The results showed that writers of English book reviews usually overuse praise and use them to open and close a book review. He also found that praise and criticism were used differently in soft and hard disciplines. "Evaluations in soft disciplines were longer, more detailed, and more discursive. On the other hand, in book reviews in hard sciences, praises were found to be dominant.

The frequencies and pragmatic purposes of metadiscourse in book reviews were investigated by Tse and Hyland (2006). The corpus included 84 reviews of books from three fields of study namely, sociology, philosophy, and biology. The analysis indicated a higher frequency of interactive and interactional metadiscourse markers in book reviews in the field of philosophy. The way writers used metadiscourse as pragmatic strategies were also shown. According to the 
literature reviewed, to the knowledge of the researcher, subcategories of interactional metadiscourse markers have not been studied in detail in the genre of the book reviews so far; therefore, the present study aimed to study the metadiscourse markers in the genre of the book reviews.

\section{Methodology}

\section{A. Corpus of the Study}

A total number of 102 English book reviews from two broad fields of soft discipline and hard discipline, with 115932 words, constituted the corpus of this study. The corpus of the soft discipline was made up of 51 book reviews in sociology, psychology, and linguistics, yielding a total of 69640 words. The book reviews of the hard discipline included 51 book reviews of three disciplines, namely, physics, chemistry, and biology, yielding a total of 46292 words. Seventeen book reviews were selected randomly from five first quality journals in each sub-discipline. These journals were taken from Oxford, Elsevier, Sage, Taylor and Frances, Science Direct, ACS, and IOP. Book reviews were published during 2007-2015.

\section{B. Rating Scale}

Hyland's (2005) interactional model of stance and engagement was employed as an analytical framework to study the frequencies of stance and engagement resources. Hyland's (2005) model includes stances and engagements. Stance has four sub-categories: hedge, booster, attitude markers and self-mention; engagement is composed of five main elements: reader pronouns, personal asides, appeals to shared knowledge, directives and questions.

\section{Data Analysis}

\section{Rating procedures}

Book reviews were thoroughly examined manually word by word to detect stance and engagement and their subcategories. These markers were highlighted and then counted manually. Furthermore, to find the frequency of stance and engagement markers in sub-sections of book reviews, the moves of book reviews (introducing, outlining, highlighting, and evaluation of the book) were identified manually according to Motta-Roth's (1995) framework. In the following samples, stance markers are bold-faced and engagement markers are underlined.

Whenever I have discussed my research interests in plagiarism with fellow instructors, I usually found that they were eager to share a plagiarism-related story with me; interestingly, nearly everyone had a story to share. Few would disagree that plagiarism is a critical issue for schools and universities in the United States and worldwide. Accordingly, plagiarism has received significant attention over the past two decades in both English L1 and L2 writing literature, as scholars have examined the many factors that are involved. (Journal of Second Language Writing, Linguistics, Elsevier, 2013)

There are 148 equations in the penultimate chapter, for example. Lengthy derivations are eliminated, though, by making them exercises for the reader. Since some of these are challenging to say the least, it is a pity that (at the time of my writing), the solutions do not appear on the publisher's website, as promised. I also found the use of 'Asides' (mini-appendices in the body of the text) rather annoying, particularly since some of the results from them are quoted in the text that follows. Should I read the Asides, or not? (Journal of Sound and Vibration, Physics, Elsevier, 2013)

2. Inter-rater Reliability

Since this analysis was subjective to some extend which is perhaps unavoidable, a $\mathrm{PhD}$ candidate who got training about this scale and became thoroughly familiar with it was asked to identify the discourse markers of $20 \%(\mathrm{~N}=20)$ of the book reviews. Then the researcher and the $\mathrm{Ph} . \mathrm{D}$. candidate checked the match in their analysis. There were slight differences found, but a consensus was reached after discussing the differences. As a statistical measure to assess interreliability, Intraclass Correlation Coefficient (ICC) was used. According to Bloch and Kraemer (1989), Intraclass Correlation Coefficient (ICC) is a measurement of agreement or consensus. The coefficient shows agreement between two or more raters or evaluation methods on the same set of data. An amount of 0.7-0.8 indicates strong agreement, and 0.8 indicates almost perfect agreement, so the value 1 represents perfect agreement and 0 shows no agreement at all. In this study, Intraclass Correlation Coefficient (ICC) between the features identified by the researcher and those identified by the Ph.D. candidate was calculated to be 0.933 which indicated almost perfect agreement.

TABLE 1

INTRACLASS CORRELATION COEFFICIENT

\begin{tabular}{llllllll}
\hline & \multicolumn{3}{c}{$95 \%$ Confidence Interval } & \multicolumn{4}{c}{ F Test with True Value 0 } \\
& Intraclass Correlation $^{\mathrm{b}}$ & Lower Bound & Upper Bound & Value & df1 & df2 & Sig \\
\hline Single Measures & $.933^{\mathrm{a}}$ & .734 & .985 & 28.893 & 8 & 8 & 8 \\
\hline
\end{tabular}

\section{RESULTS}

\section{A. Results of Stance Discourse Markers in Soft and Hard Disciplines}


As it was stated earlier, the first research question intended a difference between English book reviews of soft and hard disciplines in the use of stance discourse markers. Different subcategories of the interaction metadiscourse marker of stance are presented and compared across some soft and some hard disciplines in Table 2.

TABLE 2

FReQUENCY AND PERCENTAGe OF STANCE Discourse MARKERS In DifFERENT Disciplines

\begin{tabular}{|c|c|c|c|c|c|c|}
\hline \multirow[b]{2}{*}{$\begin{array}{c}\text { Stance } \\
\text { Features }\end{array}$} & \multicolumn{3}{|c|}{ Soft Discipline } & \multicolumn{3}{|c|}{ Hard Discipline } \\
\hline & Frequency & Percentage & $\begin{array}{c}\text { Per } 1,000 \\
\text { words }\end{array}$ & Frequency & Percentage & $\begin{array}{c}\text { Per 1,000 } \\
\text { words }\end{array}$ \\
\hline Hedge & 887 & $26.01 \%$ & 12.73 & 512 & $20.48 \%$ & 11.06 \\
\hline Booster & 1439 & $42.21 \%$ & 20.66 & 951 & $38.04 \%$ & 20.54 \\
\hline Attitude marker & 971 & $28.48 \%$ & 13.94 & 904 & $36.16 \%$ & 19.52 \\
\hline Self-mention & 112 & $3.28 \%$ & 1.60 & 133 & $5.32 \%$ & 2.87 \\
\hline Total & 3409 & $100 \%$ & & 2500 & $100 \%$ & \\
\hline
\end{tabular}

As shown in Table 2, the total number of the stance discourse markers used in soft disciplines mounted to 3409 which is higher than that of hard disciplines (3409>2500). Among subcategories of stance features in soft disciplines, boosters enjoyed the highest frequency (1439 out of 3409 words, i.e. 20.66 words per 1,000 words), while, the category self-mention ranked the last (112 out of 3409 words, i.e. 1.60 words per 1.000 words).

The next category was attitude markers which were found 971 cases out of 3409 words, that is 13.94 words out of 1,000 words. The next category was hedge markers the frequency of which in soft disciplines was 887 out of the total 3409 stance metadiscourse markers. Differently stated, the class of hedge was found in 12.73 words per 1,000. The total number of stance features in the hard disciplines were found to be 2500 with the highest frequency belonging to the class of boosters ( $n=951,20.54$ words out of 1,000 words); therefore, it can be seen that the class of boosters similarly scored the first among the stance metadiscourse markers of both soft and hard disciplines. The subcategory of selfmention with a frequency of 133 out of 2500 stances ( 2.87 per 1,000 words) was identified to be the least used class of metadiscourse markers in hard disciplines. The next class of stance metadiscourse markers was found to be attitude markers ( $\mathrm{n}=904$ of 2500 words, that is 19.52 per 1,000 words). Hedges with a frequency of 512 out of 2500 words (11.06 per 1,000 words) scored the next class of stance discourse markers. Figure 1 illustrates the frequency of subcategories of stance metadiscourse markers as occurred in soft and hard disciplines.

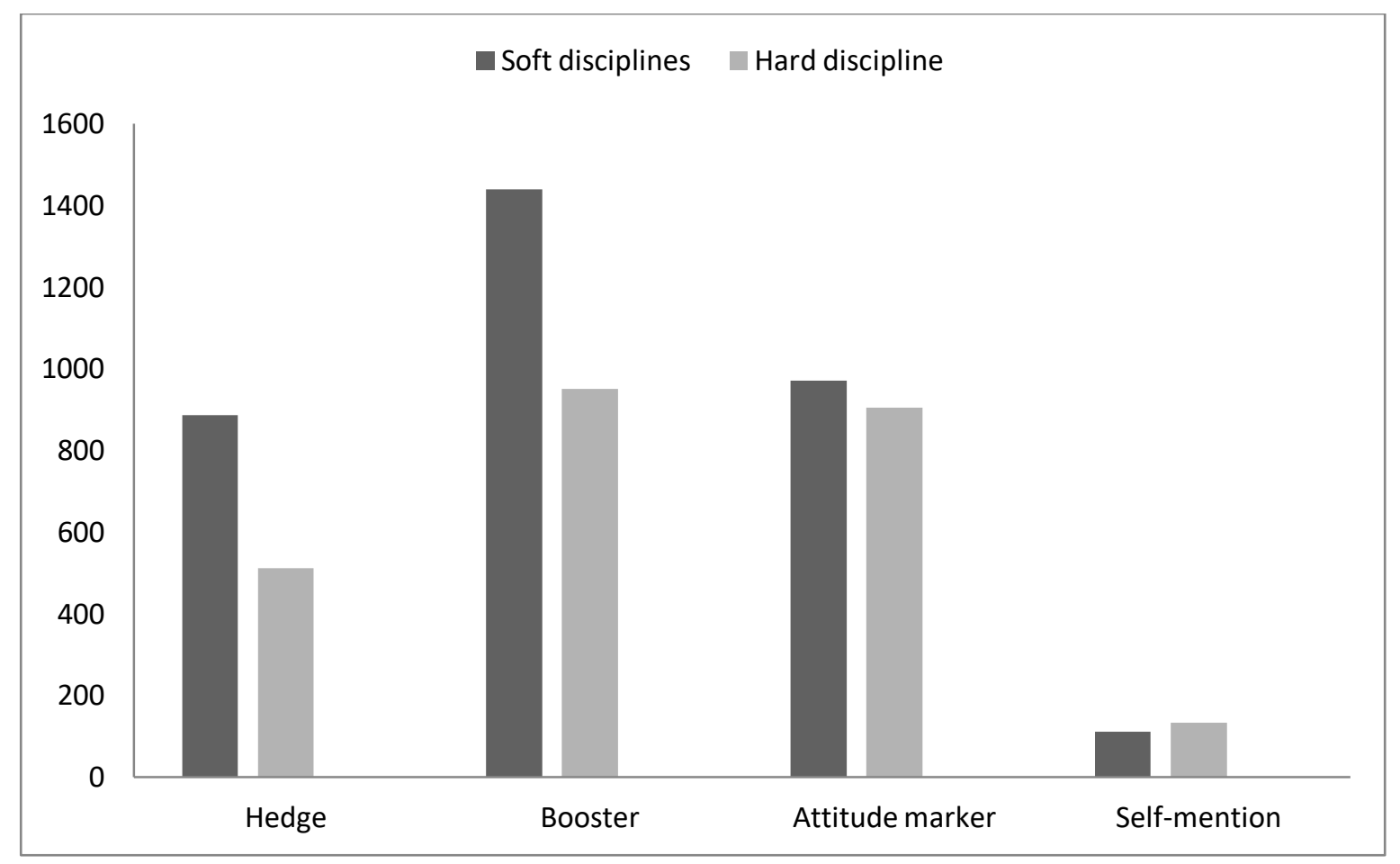

Figure 1. Frequency of Stance Features in Soft and Hard Disciplines

As shown in Figure 1, except for self-mention in the other three categories, soft disciplines included higher numbers of stance metadiscourse markers than hard disciplines. The frequency of the stance markers was compared through a Chi-square test, the results of which are presented in Table 3. 
TABLE 3

RESUlts OF CHI-SQUARE FOR USE OF STANCES DisCOURSE MARKERS IN SOFT AND HARD DisCIPLINES

\begin{tabular}{|c|c|c|c|}
\hline & Observed N & Expected N & Residual \\
\hline Soft & 3409 & 2954.5 & 454.5 \\
\hline Hard & 2500 & 2954.5 & -454.5 \\
\hline Total & 5909 & & \\
\hline Df & & & 1 \\
\hline Asymp. Sig. & & & .000 \\
\hline
\end{tabular}

According to the statistics presented in Table $3\left(\chi^{2}=139.834, p=0\right)$, the $p$ value is smaller than the significance level of .05. Therefore, the first null hypothesis of the research can be rejected and it can be claimed that there is a significant difference between English book reviews of soft and hard disciplines in the use of stance discourse markers.

\section{B. Results of Sub-categories of Stance}

To find out why the distribution of subcategories of stance is different, the Chi-Square test was run to realize the degree of the significant differences among hedges, boosters, attitude markers, and self-mentions in soft and hard disciplines. See Table 4.

TABLE 4

RESUlts OF CHI-SQUARE For USE OF DIFFERENT STANCES MARKERS IN SOFT AND HARD DisCIPLINES

\begin{tabular}{|c|c|c|c|c|c|c|c|c|c|}
\hline & \multicolumn{2}{|c|}{ Observed $\mathrm{N}$} & \multicolumn{2}{|c|}{ Expected N } & \multicolumn{2}{|c|}{ Residual } & \multirow[t]{2}{*}{ Chi-square } & \multirow[t]{2}{*}{ df } & \multirow[t]{2}{*}{ Asymp.sig. } \\
\hline & Soft & Hard & Soft & Hard & Soft & Hard & & & \\
\hline \multicolumn{10}{|l|}{ Stance } \\
\hline Hedge & 887 & 512 & 699.5 & 599.5 & 187.5 & -187.5 & 100.518 & 1 & .000 \\
\hline Booster & 1439 & 951 & 1195 & 1195 & 244 & -244 & 99.642 & 1 & .000 \\
\hline $\begin{array}{l}\text { Attitude } \\
\text { marker }\end{array}$ & 971 & 904 & 937.5 & 937.5 & 35.5 & -35.5 & 2.394 & 1 & .122 \\
\hline Self-mention & 112 & 133 & 122.5 & 122.5 & -10.5 & 10.5 & 1.800 & 1 & .180 \\
\hline
\end{tabular}

Results of Table 4 show that the $p$ value for hedges (.000) is less than the significance level (.05); therefore, it could be concluded that there was a significant difference between English book reviews of soft and hard disciplines in the use of hedge markers in favor of soft discipline $\left(\chi^{2}=100.518, p=.000<.05\right)$. Results also indicate there was a significant difference between English book reviews of soft and hard disciplines in the use of booster markers in favor of soft discipline. $\left(\chi^{2}=99.642, p=.000<.05\right)$. As shown in Table 4 the $p$ value for attitude markers turned to be .122 that could be claimed that there was not any significant difference between English book reviews of soft and hard disciplines in the use of attitude markers $\left(\chi^{2}=2.394, p=.122>.05\right)$. Also, the $p$ value for self-mentions was $.180>.05$, so there was not any significant difference between English book reviews of soft and hard disciplines in the use of self-mentions $\left(\chi^{2}=1.800, p=.180>.05\right)$.

\section{Results of Engagement Discourse Markers in Soft and Hard Disciplines}

The second research hypothesis stated that there is no significant difference between English book reviews of soft and hard disciplines in the use of engagement discourse markers. To find evidence to accept or reject this hypothesis, 102 English book reviews from six fields of study including three soft disciplines and three hard disciplines were analyzed using Hyland's (2005) model of interactional metadiscourse markers. To provide a more comprehensive view of the issue under question, some soft and hard disciplines were compared in terms of fields of study. In Table 5, engagement markers of hard and soft disciplines are compared.

TABLE 5

FREQUENCY AND PERCENTAge OF USE OF ENGAGEMENT DM In SOFT AND HARD DisCIPLINES

\begin{tabular}{|c|c|c|c|c|c|c|}
\hline \multirow{2}{*}{ Feature } & \multicolumn{3}{|c|}{ Soft Disciplines } & \multicolumn{3}{|c|}{ Hard Disciplines } \\
\hline & Frequency & Percentage & $\begin{array}{l}\text { Per } 1,000 \\
\text { word }\end{array}$ & Frequency & Percentage & $\begin{array}{c}\text { Per } 1,000 \\
\text { word }\end{array}$ \\
\hline Reader pronoun & 179 & $65.56 \%$ & 2.57 & 143 & $61.63 \%$ & 3.08 \\
\hline Shared knowledge & 21 & $7.69 \%$ & 0.30 & 34 & $14.65 \%$ & 0.73 \\
\hline Question & 41 & $15.1 \%$ & 0.58 & 48 & $20.68 \%$ & 1.03 \\
\hline Personal aside & 15 & $5.49 \%$ & 0.21 & 4 & $1.72 \%$ & 0.08 \\
\hline Directive & 17 & $6.22 \%$ & 0.24 & 3 & $1.29 \%$ & 0.06 \\
\hline Total & 273 & $100 \%$ & 3.9 & 232 & $100 \%$ & 4.98 \\
\hline
\end{tabular}

As it was stated the number of the engagement markers were counted and the results are presented the total number of words in the book reviews of soft discipline ( 69640 words) and the total number of the words in the book reviews of hard discipline (46292 words). According to the statistics presented in Table 5, out of 69640 words of soft discipline, 
273 words were found to be the engagement markers. On the other hand, 232 words out of the total 46292 words of book reviews of hard disciplines were found to be engagement markers. The difference in the total number of engagement in the book reviews of soft and hard disciplines is not much, with that of soft disciplines being a little higher than that of hard disciplines $(273>232)$. Figure 2 illustrates the frequency of subcategories of engagement metadiscourse markers as occurred in soft and hard disciplines.

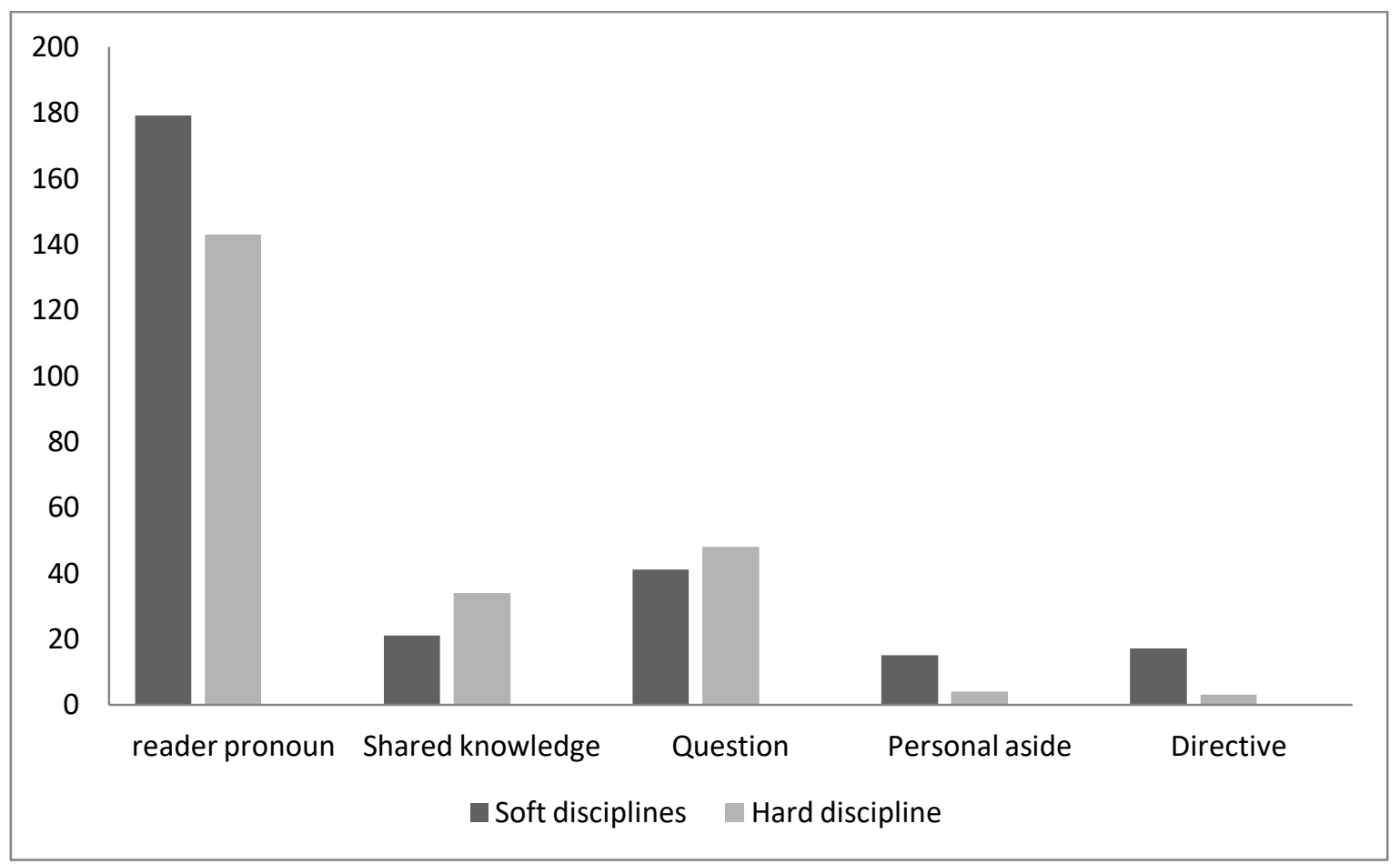

Figure 2. Frequency of Engagement Features in Soft and Hard Disciplines

To provide a comprehensive picture of the differences and similarities between the stance and engagement discourse markers, a Chi-square was run, the results of which are presented in Table 6.

TABLE 6

RESUltS OF CHI-SQUARE TEST FOR USE OF ENGAGEMENTS DM IN SOFT AND HARD DisCIPLINES

\begin{tabular}{cccc}
\hline & Observed N & Expected N & Residual \\
\hline Soft & 273 & 252.5 & 20.5 \\
Hard & 232 & 252.5 & -20.5 \\
Total & 505 & & \\
\hline Chi-Square & & 3.329 & \\
df & & .068 & \\
Asymp. Sig. & & & 1 \\
\hline
\end{tabular}

According to the results presented in Table 6 , there is no significant difference between the engagement markers of soft and hard disciplines $\left(\chi^{2}=3.329, p=.068>0.05\right)$.

D. Results of Sub-categories of Engagement

To find out the degree of the differences among reader pronouns, shared-knowledge markers, questions, personalaside markers, and directives in soft and hard disciplines, the Chi-Square test was run. See Table 7.

TABLE 7

RESUlts OF CHI-SQUARE FOR USE OF DIFFERENT ENGAGEMENT MARKERS IN SOFT AND HARD DiSCIPLINES

\begin{tabular}{|c|c|c|c|c|c|c|c|c|c|}
\hline & \multicolumn{2}{|c|}{ Observed $\mathrm{N}$} & \multicolumn{2}{|c|}{ Expected N } & \multicolumn{2}{|c|}{ Residual } & \multirow[t]{2}{*}{ Chi-square } & \multirow[t]{2}{*}{$\mathrm{df}$} & \multirow[t]{2}{*}{ Asymp.sig } \\
\hline & Soft & Hard & Soft & Hard & Soft & Hard & & & \\
\hline \multicolumn{10}{|l|}{ Engagement } \\
\hline Reader pronouns & 179 & 143 & 161.0 & 161.0 & 18.0 & -18.0 & 4.025 & 1 & .045 \\
\hline Shared-knowledge & 21 & 34 & 27.5 & 27.5 & -6.5 & 6.5 & 3.073 & 1 & .080 \\
\hline Questions & 41 & 48 & 44.5 & 44.5 & -3.5 & 3.5 & .551 & 1 & .458 \\
\hline Personal -Asides & 15 & 4 & 9.5 & 9.5 & 5.5 & -5.5 & 6.368 & 1 & .012 \\
\hline Directives & 17 & 3 & 10.0 & 10.0 & 7.0 & -7.0 & 9.800 & 1 & .002 \\
\hline
\end{tabular}


Results of Table 7 show that the $p$ value for reader pronouns (.045) is less than the significance level (.05); therefore, it can be concluded that there is a significant difference between English book reviews of soft and hard disciplines in the use of reader pronouns $\left(\chi^{2}=4.025, p=.045<.05\right)$. To further analyze, Chi-Square Test was run to realize the degree of the differences among shared knowledge in soft and hard disciplines. According to the statistics presented in Table 7 the $p$ value is .080>0.05. So, there is not any significant difference between English book reviews of soft and hard disciplines in the use of shared knowledge $\left(\chi^{2}=3.073, p=.080>0.05\right)$. Also, is not any significant difference between soft and hard disciplines in the use of questions $\left(\chi^{2}=.551, p=.458>0.05\right)$. Results of Table 7 also indicate that there is a significant difference between soft and hard disciplines in the use of personal asides $\left(\chi^{2}=6.368, p=.012<0.05\right)$. It can be claimed that there is a significant difference between English book reviews of soft and hard disciplines in the use of directives $\left(\chi^{2}=9.800, p=.002<0.05\right)$.

\section{E. Results of Stance Comparison in Moves of Book Reviews}

The present study investigated the frequency of stance features in moves of book reviews of hard and soft discipline. The total frequency of stance markers in each move of book reviews is presented in Table 8.

TABLE 8

FREQUENCY OF STANCE DISCOURSE MARKERS IN MOVES OF BOOK REVIEWS FOR SOFT AND HARD DISCIPLINES

\begin{tabular}{|c|c|c|c|c|c|c|}
\hline \multirow[b]{2}{*}{ Moves } & \multirow[b]{2}{*}{ Move Description } & \multicolumn{2}{|c|}{ Soft Discipline } & & \multicolumn{2}{|c|}{ Hard Discipline } \\
\hline & & Frequency & Percentage & $\begin{array}{c}\text { Stance } \\
\text { Features }\end{array}$ & Frequency & Percentage \\
\hline 1 & Introducing & 430 & $12.61 \%$ & & 543 & $21.72 \%$ \\
\hline 2 & Outlining & 1724 & $50.57 \%$ & & 1025 & $41 \%$ \\
\hline 3 & Highlighting & 840 & $24.64 \%$ & & 533 & $21.32 \%$ \\
\hline 4 & Evaluation & 415 & $12.17 \%$ & & 399 & $15.96 \%$ \\
\hline Total & & 3409 & $100 \%$ & & 2500 & $100 \%$ \\
\hline
\end{tabular}

As shown in Table 8, move 2 with a frequency of 1724 stances enjoyed the highest frequency of stance features in book reviews of soft discipline while move 4 with the frequency of 415 stances contained the least frequency of stance features. Move 3 and 1 are ranked in the second and third positions respectively according to the frequency of stance feature. Regarding the distribution of stance markers in moves of book reviews of hard discipline, while moves 2 presented the highest frequency of stance features, move 4 presented the least frequency of stance features. Move 1 and 3 are ranked in the second and third position respectively.

To find out the degree of difference among different moves of soft and hard disciplines (introducing, outlining, highlighting, evaluation) in the use of stance discourse markers, the Chi- Square test was run. Results of the Chi-square test for use of stance markers in different moves are presented in table 9.

TABLE 9

Results Of Chi-Square Test For Use OF Stance DM In DifFERENT Moves

\begin{tabular}{cccc}
\hline & \multicolumn{3}{c}{ Stance Features } \\
\cline { 2 - 4 } Moves & Chi-square & df & Asymp.sig. \\
\cline { 2 - 4 } Introducing & 13.123 & 1 & .000 \\
Outlining & 177.738 & 1 & .000 \\
Highlighting & 68.645 & 1 & .000 \\
Evaluation & .314 & 1 & .575 \\
\hline
\end{tabular}

Results of Table 9 show that there is a significant difference between Introducing soft and hard disciplines in the use of stance markers $\left(\chi^{2}=13.123, p=.000<.05\right)$. Results also indicate there is a significant difference between Outlining of soft and hard disciplines in the use of stance markers $\left(\chi^{2}=177.738, p=.000<.05\right)$. As shown in Table 9 there is a significant difference between Highlighting of soft and hard disciplines in the use of stance markers $\left(\chi^{2}=68.645\right.$, $p=.000<.05)$ and there is not any significant difference between Evaluation of soft and hard disciplines in the use of self-mentions $\left(\chi^{2}=.314, p=.575>.05\right)$.

\section{F. Results of Stance Comparison in Moves of Book Reviews}

The total frequency of engagement markers in each move of book reviews is also presented in Table 10. 
TABLE 10

FREQUENCY OF ENGAGEMENT MARKERS IN MOVES OF BOOK REVIEWS OF SOFT AND HARD DISCIPLINES

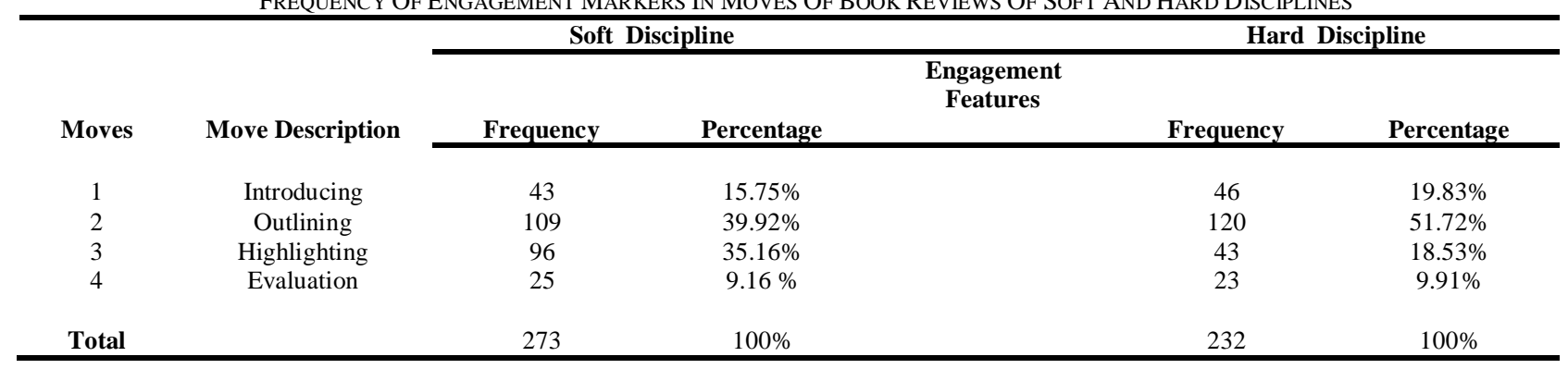

As shown in Table 10, move 2 with a frequency of 109 engagement markers enjoyed the highest frequency of engagement feature in book reviews of soft discipline while move 4 with the frequency of 25 engagement markers contained the least frequency of them. Move 3 and 1 are in the second and third rank respectively according to the frequency of engagement feature. Regarding the distribution of engagement markers in the moves of book reviews of hard discipline, while moves 2 presented the highest frequency of stance feature, move 4 presented the least frequency of engagement features. Move 1 with the frequency of 46 markers and move 3 with the frequency of 43 markers are ranked in the second and third position respectively.

To find out the degree of difference among different moves of soft and hard disciplines (Introducing, Outlining, Highlighting, Evaluation) in the use of engagement discourse markers, the Chi- Square test was run. Results of the Chisquare test for use of engagement markers in different moves are presented in Table 11.

TABLE 11

Results OF ChI-SQuARE TEST For USE OF ENGAGEMENT DM In DifFERENT MOVES

\begin{tabular}{|c|c|c|c|}
\hline \multirow[b]{2}{*}{ Moves } & \multicolumn{3}{|c|}{$\begin{array}{c}\text { EngagementFeatu } \\
\text { res }\end{array}$} \\
\hline & Chi-square & df & Asymp.sig. \\
\hline Introducing & .101 & 1 & .750 \\
\hline Outlining & .528 & 1 & .467 \\
\hline Highlighting & 20.209 & 1 & .000 \\
\hline Evaluation & .083 & 1 & .773 \\
\hline
\end{tabular}

Results of Table 11 show that there is not any significant difference between Introducing soft and hard disciplines in the use of engagement markers $\left(\chi^{2}=.101, p=.750>.05\right)$. Results also indicate there is no significant difference between Outlining of soft and hard disciplines in the use of engagement markers $\left(\chi^{2}=.528, p=.467>.05\right)$. As shown in Table 11 there is a significant difference between Highlighting of soft and hard disciplines in the use of engagement markers $\left(\chi^{2}=20.209, p=.000<.05\right)$ and there is not any significant difference between Evaluation of soft and hard disciplines in the use of self-mentions $\left(\chi^{2}=.083, p=.773>.05\right)$.

\section{CONCLUSION AND DISCUSSION}

The results regarding the first research question showed that stance markers (boosters and hedges) are more common in book reviews in soft discipline than those of hard discipline and boosters are strongly represented. The highest frequency of boosters in soft discipline suggests that soft sciences book reviewers claim their discourses with a higher degree of certainty and leave very little space for readers to give alternative opinions. The reason may be related to this point that by using boosters they want to create a sense of mutual understanding.

This result is compatible with the results found by Hyland (2005a). According to (Hyland 2005a) "both hedges and boosters tended to be more common in the humanities and social science papers. This can be attributed to the fact that the soft-knowledge fields are usually more interpretive and less abstract than the hard sciences and their forms of argument rely more on a dialogic engagement and more explicit recognition of alternative voices" (p. 145). This finding is in line with findings found by Tse and Hyland (2006) who found a large number of hedges and boosters in book reviews in philosophy compared with biology. Hyland (2010) claimed that hedges and boosters which indicate the degree of caution, help writers construct proximity with readers._Hedges show that a claim matches with the writer's reasoning rather than certain knowledge.

The highest number of hedges and boosters was found in linguistics. The results of the present research lend support to the study by Junqueira and Cortes (2014), who found that interpersonal metadiscourse devices like hedges were more frequent in the book reviews in the English corpus across the three subfields of soft disciplines, namely, History and Psychology, and applied Linguistics. This is in line with the study by Salahshoor and Afsari (2017) who investigated interactional metadiscourse in natural and social science master theses, and found that hedges were the most frequent marker in both corpora while attitude markers in social science and self-mention in natural science were the least favored role. 
The findings also lend support to the study by $\mathrm{Hu}$ and Cao (2011) which investigated the use of hedges and boosters in academic article abstracts and showed that hedges in abstracts published in English-medium journals were more frequent than those published in Chinese-medium.

Furthermore, the results suggested that the writers of book reviews tended to use self-mention a little more in hard discipline than soft discipline, but this difference was not significant. This finding is in line with findings found by Tse and Hyland (2006) about the equal number of self-mentions in philosophy and biology. This result is incompatible with the result found by Hyland (2005a) about the high proportion of self-mention in the humanities and social science papers. According to Hyland (2005a) "establishing an appropriately authorial persona and maintaining an effective degree of personal engagement with one's audience are valuable strategies for probing relationships and connections between entities that are generally more particular, less precisely measurable and less clear cut than in the hard sciences" (p. 148).

According to the result, although attitude markers were more in book reviews of soft discipline than those of hard discipline, this difference was not significant. This result is compatible with the findings of Hyland (2005), and Hyland (2010). According to him writers in soft articles can express their feelings and emotions easier than hard articles in which some scientific facts are reported. As the findings of this study revealed the writers of book reviews of soft discipline are more inclined to express their feelings towards the text and therefore use more attitude markers. The results of the present research are against the study by Junqueira and Cortes (2014), in which it was found attitude markers were the least frequent in the English and Brazilian Portuguese (BP) book reviews across the three subfields of soft disciplines, namely, History and Psychology, and applied Linguistics.

Regarding the findings related to research question 2, it can be claimed that there was no significant difference between English book reviews of soft and hard disciplines in the use of engagement markers. This result is in line with the findings of the study conducted by Tse \& Hyland (2006). They concluded that Engagement markers were the most frequently used features in both the philosophy and biology texts. In both disciplines, it is necessary to use devices such as engagement markers to construct writer-reader relations and create a sense of solidarity.

Regarding move analysis move 2, outlining the book, is usually the longest move in both book reviews of soft and hard disciplines, so it is reasonable that it holds more stance and engagement features. Writers of book reviews highlight and evaluate specific parts of books through move 3, high lighting the book. In book reviews of soft discipline due to its nature, reviewers find more opportunity to give their opinions on specific chapters, so it is tried to use a high number of stance and engagement feature in this move to build proximity with readers and writers of books. Due to this fact that move 4 is the final evaluation of the book and the writers of book reviews try to recommend or reject books based on final evaluation as well as this point that in most cases this move is quite short, it is expected that this move contains the least stance and engagement features in both disciplines.

The findings of this study could enrich the literature in the area of research, especially in an Iranian context. The findings of this study may recommend that during the writing and research courses at university, teachers include some exercises on genre-based instruction in their course content. Furthermore, the findings will be applied to the field of language teaching by helping English language teachers to use new techniques in their classes to develop their students' writing skill. The results of this study can be useful for postgraduate students, in that it can help them enhance their research knowledge and publish book reviews, in addition to research articles. This study can help students know how to learn writing effectively. Besides, this study can be a source of information for another researcher who wants to conduct the same research.

\section{AppendiX. Samples of Move Analysis of Book Reviews of Soft And HaRd Disciplines}

\begin{tabular}{|c|c|}
\hline Move & SAMPLE BOOK REVIEWS \\
\hline $\begin{array}{c}\text { Move } 1 \\
\text { (Introducing) }\end{array}$ & $\begin{array}{l}\text { In the recent book Changing Minds or Changing Channels? Partisan News in an Age of Choice, Kevin Arceneaux } \\
\text { and Martin Johnson examine the effects of partisan cable news. They propose that the small, and unique audience } \\
\text { drawn to partisan cable news blunts its possible effects. }\end{array}$ \\
\hline $\begin{array}{l}\text { Move } 2 \\
\text { (Outlining) }\end{array}$ & $\begin{array}{l}\text { The book is organized into eight chapters. The first chapter focuses on the contested nature of power and sketches } \\
\text { out the dual ways in which power is typically conceptualized (e.g. as a capacity versus as a possession). }\end{array}$ \\
\hline $\begin{array}{c}\text { Move } 3 \\
\text { (Highlighting) }\end{array}$ & $\begin{array}{l}\text { I see two shortcomings that, in the end, do not detract significantly from the overall contribution of the book. First, } \\
\text { chapters four and five ("This Body Is No Longer My Own" and "Making Rooms for Babies") stray a bit from the } \\
\text { strong connection the author makes throughout the book to the practices of ordinary pregnancy. } \\
\text { We see little practical application for Chapter } 6 \text {. The more mathematical sections (Chapters } 2 \text { and } 3 \text { ) are heavy } \\
\text { going and these we leave for others to judge. They are clearly sign-posted, so it is easy for the reader to skip them } \\
\text { if preferred, as we have done. }\end{array}$ \\
\hline $\begin{array}{c}\text { Move } 4 \\
\text { (evaluation) }\end{array}$ & $\begin{array}{l}\text { In summary, Beyond Caring Labour to Provisioning Work is a volume of importance to academics, researchers and } \\
\text { members of the public who share a passion and interest for how women work and the nature of such work in a } \\
\text { social context that counts and even notices only the smallest measure of the work they do. }\end{array}$ \\
\hline
\end{tabular}




\section{REFERENCES}

[1] Abdollahzadeh, E. (2011). Poring over the findings: interpersonal authorial engagement in applied linguistics papers. Journal of Pragmatics, 43, 288-297. https:// doi.org/10.1016/j.pragma.2010.07.019.

[2] Atai, M. R., \& Sadr, L. (2008). A cross-cultural study of hedging devices in discussion section of applied linguistics research articles. Teaching English Language and Literature Society of Iran (TELLSI), 2(7), 1-2.

[3] Ebrahimi, S., J. (2018). The Role of Metadiscourse Markers in Comprehending Texts of Reading Comprehension Books Published in Iran and Oxford University Press. International Journal of Applied Linguistics \& English Literature. 7(3), 90-96.

[4] Faghih, E., \& Rahimpour, S. (2009). Contrastive rhetoric of English and Persian written text: Metadiscourse in applied linguistic research articles, Rice Working Papers in Linguistic, 1, 92-107.

[5] Fuertes-Olivera, P. A., Velasco-Sacrist.n, M., Arribas-Bano, A., \& Samiengo-Fern.ndez, E. (2001). Persuasion and advertising English: Metadiscourse in slogans and headlines. Journal of Pragmatics, 33, 1291-1307. https://doi.org/10.1016/S03782166(01)80026-6.

[6] Gea Valor, M. L. (2000). The pragmatics of positive politeness in the book review. Resla, 14,145-159.

[7] Gezegin, B., B. (2016). A Corpus-based Investigation of Metadiscourse in Academic Book Reviews. Procedia - Social and Behavioral Sciences, 232, 713-718.

[8] Ghafoori, N. \& Oghbatalab, R. (2012). A Comparative Study of Metadiscourse in Academic Writing: Male vs. Female Authors of Research. Articles in Applied Linguistics. The Journal of Applied Linguistics, 5(1), 87-113.

[9] Ghazanfari, M., Barani, G. \& Rokhsari, S. (2018). An Investigation into Metadiscourse Elements Used by Native vs. NonNative University Students across Genders. Iranian Journal of Applied Language Studies, 10 (1), 60-94.

[10] Hyland, K. (2000). Disciplinary discourse: Social interactions in academic writing. London: Longman.

[11] Hyland, K. (2000). Hedges, Boosters and lexical invisibility: noticing modifiers in academic texts. Language Awareness, 9 (4), 179-197. https://doi.org/10.1080/09658410008667145.

[12] Hyland, K. (2000). Praise and criticism: Interactions in book reviews. In K. Hyland (Ed.), Disciplinary discourses: Social interactions in academic writing (pp.41-62). Harlow, England: Longman.

[13] Hyland, K. (2001b). Humble servants of the discipline? Self-mention in research articles. English for Specific Purposes, 29(3), 207-226. https://doi.org/10.1016/S0889-4906(00)00012-0.

[14] Hyland, K. (2002). Directives: Power and engagement in academic writing. Applied Linguistics, 23(2), $215-239$.

[15] Hyland, K. (2003). Genre-based pedagogies: A social response to process. Journal of Second Language Writing, 12, 17-29. https://doi.org/10.1016/S1060-3743(02)00124-8.

[16] Hyland, K. (2004). Disciplinary interactions: Metadiscourse in L2 postgraduate writing. Journal of Second Language Writing, 13(2), 133-151. https://doi.org/10.1016/j.jslw.2004.02.001.

[17] Hyland, K., \& Tse, P. (2004). Metadiscourse in academic writing: A reappraisal. Applied Linguistics, 25, 156-177. https://doi.org/10.1093/applin/25.2.156.

[18] Hyland, K. (2005a). Metadiscourse. Exploring interaction in writing. London/New York: Continuum.

[19] Hyland, K. (2005b). Stance and engagement: a model of interaction in academic discourse. Discourse Studies, 7, $173-192$. https://doi.org/10.1177/1461445605050365.

[20] Hyland, K. (2008b). Persuasion, Interaction and the Construction of Knowledge: Representing Self and Others in Research Writing. International Journal of English Studies, 8 (2), 1-23.

[21] Hyland, K. \& Diani, G. (2009). Introduction: Academic evaluation and review genres. In K. Hyland \& G. Diani (Eds.), Academic Evaluation. Review Genres in University Settings (pp. 1-14). Houndmills: Palgrave Macmillan.

[22] Hyland, K. (2010). Constructing proximity: Relating to readers in popular and professional science. Journal of English for Academic Purposes, 9, 116-127. https://doi.org/10.1016/j.jeap.2010.02.003.

[23] Jalilifar, A., Hayati, S. \& Don, A. (2018). Investigating Metadiscourse Markers in Book Reviews and Blurbs: A Study of Interested and Disinterested Genres. Studies about Languages, 33, 90-117.

[24] Junqueira, L. \& Cortes, V. (2014). Metadiscourse in book reviews in English and Brazilian Portuguese: A corpus-based analysis. Rhetoric, Professional Communication, and Globalization.6, 88-109.

[25] McGrath, L., \& Kuteeva, M. (2012). Stance and engagement in pure mathematics research articles: Linking discourse features to disciplinary practices, English for Specific Purposes, 31, 161-173. https://doi.org/10.1016/j.esp.2011.11.002.

[26] Miller, C. (1994). Genre as social action. Quarterly Journal of Speech, 70, $151-167$. https://doi.org/10.1080/00335638409383686.

[27] Salahshoor, F. \& Afsari, P. (2017). An Investigation of Interactional Metadiscourse in Discussion and Conclusion Sections of Social and Natural Science Master Theses. The Journal of Applied Linguistics and Applied Literature: Dynamics and Advances, $5(2), 7-14$.

[28] Swales, J. (1990). Genre analysis: English in academic settings. Cambridge University Press.

[29] Tse, P. \& Hyland, K. (2006). So what is the problem this book addresses? Interactions in academic book reviews. Text \& Talk 26(6), 767-790. https:// doi.org/10.1515/ TEXT. 2006. 031.

[30] Vande Kopple, W. (1985). Some explanatory discourse on metadiscourse. College Composition and Communication 36, 82-93.

[31] Yang, Y. (2014). Exploring linguistic and cultural variations in the use of hedges in English and Chinese scientific discourse. Journal of Pragmatics, 50, 23-36. https:// doi.org/ 10.1016/ .pragma. 2013.01.008.

Neda Zal was born in Isfahan, Iran in 1978. She received her Master's degree in Teaching English as a Foreign Language (TEFL) from the department of language in University of Kashan, Kashan, Iran in 2017

She has been working as an English teacher for more than 20 years in language institutions in Isfahan, Iran. She has been teaching IELTS for more than 10 years and she has translated several Medical articles. 
Other work experience include: A member of Translator Group, International Intangible Cultural Heritage Festival \& General Assembly (ICCN 2014)

Team member of Translator Group, The 18th General International Assembly of the World Crafts Council, Sep 2016

Mohammad Raouf Moini was born in Isfahan, Iran in 1968. Educational backgrounds include:

Ph.D in TEFL, English Department, University of Shiraz, Shiraz, Iran, 2003

M.A. in TEFL: English Department, Tarbiat Modarres, Tehran, Iran, 1992

B.A. in TEFL: English Department, University for Teachers' Education, Tehran, Iran, 1990.

$\mathrm{He}$ is the retired assistant professor of TEFL, Department of English, University of Kashan, Iran. Regarding work experience, he worked as an Assistant Professor of TEFL, Department of English, University of Kashan Iran, A Member of ASIA TEFL and Head of Department of English Literature, University of Kashan, Iran 2004-2003-2005. He has published research papers and books including: Expand your reading ability: an Enjoyable EFL reader. Tehran. Iran. Jungle Publication, 2004 \& Research methods and designs in humanities. Tehran: Jungle Publication, 2008. Papers: Moini, M. R. (2008). Bottom-up and top-down processing in C-test performance: A cognitive model Journal of Humanities, Al.Zara University. 18 (72). 129-53. Moini. M. R., (2009). The impact of EFL teachers' cognition on teaching foreign language Grammar. Pazhuhesh-e zabanha-ye Khareji. 49, 141-164. 